\title{
Prediction of coagulating and noncoagulating milk samples using mid-infrared spectroscopy
}

\author{
M. De Marchi, ${ }^{1}$ V. Toffanin, M. Cassandro, and M. Penasa \\ Department of Agronomy, Food, Natural Resources, Animals and Environment, University of Padova, Viale dell'Università 16, 35020 Legnaro, \\ Italy
}

\section{ABSTRACT}

Recently, a general deterioration of milk coagulation properties (MCP) has been observed in Italy; thus, the prediction of noncoagulating ( $\mathrm{NC}$ ) milk, defined as milk not forming a curd within $30 \mathrm{~min}$ from rennet addition, is of immediate interest in the Italian cheese industry. The present study investigated the ability of mid-infrared (MIR) spectroscopy to predict NC milk using individual and bulk samples from Holstein cows. Samples were selected according to MIR analysis to cover the range of coagulation time between 5 and 60 min. Milks were then analyzed for MCP through the reference instrument (Formagraph) over an extended testing period of 60 min to identify coagulating and NC samples. Measured traits were rennet coagulation time, curd-firming time, and curd firmness 30 and 60 min after rennet addition. Results showed no specific spectral information distinguishing $\mathrm{NC}$ from coagulating samples. The most accurate prediction model was developed for rennet coagulation time followed by curdfirming time and curd firmness 30 min after rennet addition, whereas curd firmness 60 min after enzyme addition could not be accurately predicted. Based on these findings, MIR spectroscopy might be proposed in payment systems to reward or penalize milk according to MCP. Moreover, the ability of MIR spectroscopy to predict the MCP of samples that form a curd beyond 30 min from enzyme addition may be of interest for genetic improvement of coagulation traits in dairy breeds, because until now most studies have excluded $\mathrm{NC}$ information from genetic analysis, leading to possible biases in the estimation of genetic parameters and in the prediction of sire's merit for MCP.

Key words: mid-infrared spectroscopy, milk coagulation property, Holstein-Friesian, phenotyping

Received December 19, 2012.

Accepted March 7, 2013.

${ }^{1}$ Corresponding author: massimo.demarchi@unipd.it

\section{INTRODUCTION}

The Italian dairy industry relies heavily on milk coagulation properties (MCP), as they influence the efficiency of cheese-making process (Pretto et al., 2013). Milk with good aptitude to coagulate after rennet addition and to form a firm curd has been associated with increased cheese yield compared with milk that reacts poorly to the presence of the enzyme (Bynum and Olson, 1982; Riddell-Lawrence and Hicks, 1989; De Marchi et al., 2008). During the last decades, MCP have been deteriorating in Italy (Sandri et al., 2001), with an elongation of the rennet coagulation time (RCT; min) and an increase of the percentage of noncoagulating (NC) milk, which has been conventionally defined as milk not forming a curd within the testing time of $30 \mathrm{~min}$ (e.g., Ikonen et al., 1999; Tyrisevä et al., 2003) or $31 \mathrm{~min}$ (e.g., Ikonen et al., 2004; Cassandro et al., 2008; Penasa et al., 2010) after rennet addition. As the proportion of cows producing NC milk is increasing, a negative effect on profitability and efficiency of the dairy sector is expected. Noncoagulating milk is detrimental for the cheese industry and, thus, it is economically penalized in certain dairy chains, such as in Parmigiano-Reggiano and Trentingrana cheese production, where coagulation traits are determined by the Formagraph and are considered in milk quality payment system. Also, blending well-coagulating milk with NC (Frederiksen et al., 2011) or poorly coagulating (Okigbo et al., 1985b) milk compromises the MCP of the resulting mix.

Several studies on MCP faced the problem of $\mathrm{NC}$ samples and investigated causes underlying their occurrence. Although neither environmental nor genetic factors can thoroughly explain the phenomenon, associations of NC milk with $\mathrm{pH}$ (Okigbo et al., 1985c; Tyrisevä et al., 2003), SCC and mastitis (Okigbo et al., 1985a), k-CN concentration and genotypes (Wedholm et al., 2006; Hallén et al., 2010; Frederiksen et al., 2011), and stage of lactation (Okigbo et al., 1985c; Tyrisevä et al., 2003; Ikonen et al., 2004) have been reported. Moreover, Harzia et al. (2012) found that the metabolic profile of NC milk was significantly different 
from that of well-coagulating milk, and thus a relationship between metabolic profile and MCP exists. The same authors compared NC and well-coagulating milk and highlighted significant differences in terms of $\mathrm{pH}$, SCS, and fat, protein, and urea contents.

Besides environmental factors, breed and additive genetic effects also seem to influence the occurrence of NC milk. Marked differences exist in the proportion of NC samples among cattle breeds; for example, the proportion has been reported as 8 to $13.2 \%$ in Finnish Ayrshire (Ikonen et al., 1999, 2004; Tyrisevä et al., 2003, 2004), 1.3 to $9.7 \%$ in Holstein-Friesian (Tyrisevä et al., 2004; Cassandro et al., 2008), and 0.3\% in Estonian Holstein (Vallas et al., 2010). However, the comparison of the occurrence of $\mathrm{NC}$ samples from different breeds should be made with caution, as the experimental conditions often differ among studies, particularly in terms of sampling procedures and analytical conditions, such as the use or not of preservatives in the milk, the age of sample, the type of instrument (e.g., mechanical vs. optical), the type and activity of the coagulant, and the temperature of analysis (Pretto et al., 2011; CipolatGotet et al., 2012). Evidence exists that additive genetic effects (Ikonen et al., 1999, 2004; Tyrisevä et al., 2003, 2004) and 2 potential candidate genes (Tyrisevä et al., 2008) are associated with the noncoagulation of milk, and that large differences in the proportion of daughters with NC milk among sires are present. Although several studies discarded NC samples from the genetic analysis, the inclusion or not of NC milk information in statistical models aiming at estimating covariance components for MCP has an influence on the assessment of genetic parameters for coagulation traits (Ikonen et al., 2004; Cecchinato et al., 2011).

Few studies have dealt with measures of MCP beyond the conventional time of 30 to 31 min after coagulant addition (Mariani et al., 1997; Auldist et al., 2002, 2004; O'Brien et al., 2002; Frederiksen et al., 2011; Cipolat-Gotet et al., 2012). Extending the coagulation analysis beyond this threshold may notably reduce the proportion of $\mathrm{NC}$ milks as longer time is allowed for the sample to coagulate (Cipolat-Gotet et al., 2012). However, the use of traditional instruments (e.g., the Formagraph) to determine MCP is applicable only to small-scale experiments and not at population level.

Mid-infrared (MIR) spectroscopy has been recently evaluated as a potential tool to collect MCP data at the population level for phenotypic and genetic purposes (Dal Zotto et al., 2008; Cecchinato et al., 2009; De Marchi et al., 2009). De Marchi et al. (2009) discussed the prediction of RCT and curd firmness 30 min after rennet addition $\left(\mathbf{a}_{\mathbf{3 0}} ; \mathrm{mm}\right)$ through MIR spectroscopy using coagulated samples of Brown Swiss cows and found which models were most applicable for RCT.
However, MIR spectroscopy predictions of individual samples may play an important role as indicator traits in selective breeding to enhance MCP. No studies are currently available in the literature that attempted to predict NC samples. Therefore, the aim of this work is to investigate the capability of MIR spectroscopy to predict coagulating and $\mathrm{NC}$ milk in dairy cows.

\section{MATERIALS AND METHODS}

\section{Milk Samples Collection and Reference Analysis}

In September 2011, prediction models for MCP were installed on Milko-Scan FT6000 (Foss Electric A/S, Hillerød, Denmark) in the laboratory of the Breeders Association of Veneto region (ARAV, Padova, Italy) and were used for routine analysis of MCP on samples collected during monthly test-day milk recording. Midinfrared spectroscopy calibration models were developed by De Marchi et al. (2009, 2012) and exhibited coefficients of determination in cross-validation of 0.76 and 0.70 for RCT and $\mathrm{a}_{30}$, respectively (De Marchi et al., 2012). The use of MIR spectroscopy models allowed the prediction of MCP only for samples that coagulated within 30 min after rennet addition.

To assess the capability of MIR technology to predict NC samples, individual and bulk milks from HolsteinFriesian cows were collected in the Veneto region of Italy from November 2011 to February 2012. Immediately after sampling, milks were treated with preservative (Bronopol, Knoll Pharmaceuticals, Nottingham, UK), transferred to the laboratory of the Breeders Association of Veneto region (ARAV, Padova, Italy), and selected according to MIR spectroscopy analysis. The aim of the selection process was to store samples (once per week) that covered a wide range of RCT, from very early coagulation (i.e., within $10 \mathrm{~min}$ after enzyme addition) to very late coagulation (i.e., more than 30 min after enzyme addition). As a result, spectral information from 200 individual milks from 5 dairy herds and 135 bulk milks were extracted from the MIR database and analyzed for MCP within 2 to $5 \mathrm{~d}$ from collection through the reference method (Formagraph; Foss Electric A/S) over an extended testing time of 60 min to allow the determination of coagulation characteristics of NC milks (Ikonen et al., 1999; Cassandro et al., 2008; De Marchi et al., 2009). Samples (10 mL) were heated to $35^{\circ} \mathrm{C}$ and $200 \mu \mathrm{L}$ of a rennet solution (Hansen Standard 160; Pacovis Amrein AG, Bern, Switzerland) diluted to $1.6 \%(\mathrm{w} / \mathrm{v})$ in distilled water was added at the start of analysis. Besides RCT and $\mathrm{a}_{30}$, measured traits were curd-firming time $\left(\mathbf{k}_{\mathbf{2 0}}\right.$; the time interval, in minutes, from the addition of rennet to the time at which the width of the graph attains 20 
$\mathrm{mm}$ ) and curd firmness $60 \mathrm{~min}$ after rennet addition $\left(\mathbf{a}_{60} ; \mathrm{mm}\right)$. All samples coagulated within $60 \mathrm{~min}$ from enzyme addition.

\section{MIR Spectra Acquisition and Multivariate Data Analysis}

Mid-infrared spectra were selected from stored data and were initially collected from $0.25 \mathrm{~mL}$ of sample over the spectral range of 4,000 to $900 \mathrm{~cm}^{-1}$ using a Milko-Scan FT6000 (Fourier transform infrared interferometer; Foss Electric A/S) within $4 \mathrm{~h}$ from reference analysis.

Prediction models were obtained from The Unscrambler software (version 9.6; Camo A/S, Oslo, Norway). To optimize the accuracy of the calibration, the data underwent two treatments. (1) Detection of anomalous spectra in the calibration data set, accomplished using the Mahalanobis distance (Global H statistics) to the center of the population (Williams and Norris, 2001); samples $>3$ were considered outliers and were removed from the calibration data set so that the final data available for investigation accounted for 319, 147, 224, and 178 samples for RCT, $\mathrm{k}_{20}, \mathrm{a}_{30}$, and $\mathrm{a}_{60}$, respectively. (2) Different combinations of scattering corrections and derivative mathematical treatments; normalized and multiplicative scatter corrected, first derivative (Savitzky-Golay, 3 data points each side), and normalized plus first derivative according to Williams (2001) and De Marchi et al. (2009). However, no significant improvement was found compared with the use of untreated spectra, as reported by De Marchi et al. (2009).

Statistical analysis was carried out using principal component analysis (PCA) and partial least squares (PLS) regression analysis. Spectral data subjected to PCA and PLS produced a new and smaller set of variables called principal components and loadings (\#L), respectively. Principal component analysis provides graphical representations of similarities and differences across spectra, and was employed to investigate sample distribution (Martens and Naes, 1989) and discriminate $\mathrm{NC}$ milks from samples that coagulated within $30 \mathrm{~min}$ from enzyme addition.

The optimal number of \#L was calculated as the number of \#L after which the standard error of crossvalidation $\left(\mathbf{S E C}_{\mathbf{C V}}\right)$ no longer decreased substantially. Prediction models were confirmed using the crossvalidation method by dividing the calibration data set in 10 subgroups; 9 of them were used to construct the calibration model and 1 to check the results. This operation was repeated until all groups were treated both as calibration and prediction set. The effectiveness of calibration and validation models was assessed using the standard error of calibration, $\mathrm{R}^{2}, \mathrm{SEC}_{\mathrm{CV}}$, and coefficient of determination of cross-validation (1-VR). According to Williams (2003), values of 1-VR between 0.50 and 0.65 indicate poor predictions; values between 0.66 and 0.81 indicate fairly accurate predictions; and values greater than 0.82 reveal good predictions.

The ratio performance deviation (RPD) and the range error ratio (RER) were calculated to provide indications on the practical utility of predictive models. The RPD is the ratio of the $\mathrm{SD}$ to $\mathrm{SEC}_{\mathrm{CV}}$ of a given trait and RER is the ratio of the $\mathrm{SEC}_{\mathrm{CV}}$ of the trait relative to the range of the reference data (Edney et al., 1994; Williams, 2001). High values of RPD are desirable; in particular an RPD greater than 2 enables good predictions (Sinnaeve et al., 1994; De Marchi et al., 2011). The RER is a method for standardizing the $\mathrm{SEC}_{\mathrm{CV}}$ by relating it to the range of the reference data. For example, RER values lower than 6 indicate very poor classification and are not recommended for any application; RER values between 7 and 20 classify the model as poor to fair and indicate that the model could be used for screening purposes; and RER values between 21 and 30 indicate a good classification, suggesting that the model would be suitable for a role in a quality control application (Williams, 2001).

\section{RESULTS AND DISCUSSION}

\section{MCP}

Descriptive statistics of $\mathrm{MCP}$ are summarized in Table 1 . Rennet coagulation time, $\mathrm{k}_{20}, \mathrm{a}_{30}$, and $\mathrm{a}_{60}$ averaged $30.55 \mathrm{~min}, 9.61 \mathrm{~min}, 26.97 \mathrm{~mm}$, and $14.76 \mathrm{~mm}$, respectively. The CV ranged from 47 (RCT) to $68 \%\left(\mathrm{k}_{20}\right)$, suggesting a wide degree of variability, which should facilitate the development of robust prediction models. The comparison with other studies is difficult because our results originated from selected $\mathrm{NC}$ samples. If milks with RCT longer than 30 min are removed from the data set (data not shown), RCT and $\mathrm{a}_{30}$ averaged $16.51 \mathrm{~min}$ and $29.36 \mathrm{~mm}$, respectively, which are similar to findings reported by Cassandro et al. (2008) in Italian Holstein cows. However, RCT of samples that coagulated within $30 \mathrm{~min}$ are longer than results from De Marchi et al. (2009) in Brown Swiss cows and Ikonen et al. (2004) in Finnish Ayrshire breed.

\section{MIR Spectra and PCA Analysis of NC Milk Samples}

Prediction models were obtained using modified spectra according to several authors (Pillonel et al., 2003; Dal Zotto et al., 2008; De Marchi et al., 2009, 2011) who suggested omitting the spectral regions related to low signal-to-noise ratio. In the present study, the spectral regions 3,040 to $3,470 \mathrm{~cm}^{-1}$ and 1,600 to $1,700 \mathrm{~cm}^{-1}$ 
Table 1. Descriptive statistics of milk coagulation properties

\begin{tabular}{lcrrrcc}
\hline Trait $^{1}$ & $\mathrm{n}^{2}$ & Mean & \multicolumn{1}{c}{ SD } & CV & Minimum & Maximum \\
\hline RCT, min & 319 & 30.55 & 14.30 & 0.47 & 7.75 & 59.00 \\
$\mathrm{k}_{20}$, min & 147 & 9.61 & 6.58 & 0.68 & 2.00 & 28.45 \\
$\mathrm{a}_{30}, \mathrm{~mm}$ & 224 & 26.97 & 13.88 & 0.51 & 0.36 & 51.30 \\
$\mathrm{a}_{60}, \mathrm{~mm}$ & 178 & 14.76 & 9.18 & 0.62 & 0.76 & 40.96 \\
\hline
\end{tabular}

${ }^{1} \mathrm{RCT}=$ rennet coagulation time of samples that coagulated within 60 min from enzyme addition; $\mathrm{k}_{20}=$ curdfirming time of samples attaining $20 \mathrm{~mm}$ of firmness within $60 \mathrm{~min}$ from enzyme addition; $\mathrm{a}_{30}=$ curd firmness 30 min after enzyme addition; $\mathrm{a}_{60}=$ curd firmness 60 min after enzyme addition.

${ }^{2}$ Number of samples used in the calibration after removing outliers.

were found to have high noise levels and, thus, were discarded before the analysis; these regions were related to the absorption of water as reported by Hewavitharana and Brakel (1997) and Jørgensen and Næs (2004). The analyzed spectra showed specific peaks, as previously reported by De Marchi et al. (2009, 2011): 1,550 to $1,570 \mathrm{~cm}^{-1}$ related to protein absorption (Curley et al., 1998; Etzion et al., 2004); 2,800 to $3,000 \mathrm{~cm}^{-1}, 2,855$ to $2,928 \mathrm{~cm}^{-1}$, and 1,805 to $1,736 \mathrm{~cm}^{-1}$ related to lipid absorption (Coates, 2000; Lefèvre and Subirade, 2000); and 900 to $1,500 \mathrm{~cm}^{-1}$ related to $\mathrm{C}-\mathrm{H}$ bending $(1,493$ $\mathrm{cm}^{-1}$ ) and C-O stretching (1,080 and 1,157 $\left.\mathrm{cm}^{-1}\right)$.

Principal component analysis of the untreated spectra allowed the investigation of the influence plot and the identification of outliers. Milk samples did not show extreme values of leverage and residual variance, and thus none of them was classified as an outlier. The score plot of first and second principal components provided information on samples distribution; in particular, samples were classified in 2 categories, namely those with RCT longer than 30 min and those with RCT shorter than $30 \mathrm{~min}$, with the purpose of investigating spectral information from well-coagulating and NC milks.

Principal components 1 and 2 explained 86 and $8 \%$ of the observed variation in the spectra, respectively (Figure 1). The plot clearly depicts the mixing of all samples, indicating that no specific spectral information related to well-coagulating and NC milk exists. This outcome was somewhat expected, as the potential of MIR spectroscopy to predict MCP is related to specific protein and lipid peaks (De Marchi et al., 2009), and NC samples did not differ in chemical composition from well-coagulating milk. According to results from PCA, a discriminant analysis (presence or absence of $\mathrm{NC}$ samples) is not feasible; the only way to rapidly predict NC samples is to develop MIR prediction models using milk with a wide range of RCT (from 30-60 min).

\section{Prediction of Rennet Coagulation Time, Curd-Firming Time, and Curd Firmness}

Fitting statistics of prediction models for MCP using untreated spectra are in Table 2. Prediction models were developed using 3 MIR spectral regions: 900 to $1,600 \mathrm{~cm}^{-1}, 1,700$ to $3,040 \mathrm{~cm}^{-1}$, and 3,470 to 4,000 $\mathrm{cm}^{-1}$. The number of modified PLS factors used in the calibration ranged from $12\left(\mathrm{k}_{20}\right)$ to $17\left(\mathrm{a}_{30}\right)$, which is slightly lower than that reported by De Marchi et al. (2009). The most accurate prediction model was developed for RCT (1-VR and $\mathrm{SEC}_{\mathrm{CV}}$ of 0.76 and 7.05 min, respectively), followed by $\mathrm{k}_{20}$ (1-VR and $\mathrm{SEC}_{\mathrm{CV}}$ of 0.72 and $3.54 \mathrm{~min}$, respectively), and $\mathrm{a}_{30}$ (1-VR and $\mathrm{SEC}_{\mathrm{CV}}$ of 0.70 and $7.68 \mathrm{~mm}$, respectively). Models for the prediction of $\mathrm{a}_{60}$ were not satisfactory (1-VR and $\mathrm{SEC}_{\mathrm{CV}}$ of 0.40 and $7.26 \mathrm{~mm}$, respectively). Regarding the practical utility of the prediction models, RPD and RER ranged from $1.26\left(\mathrm{a}_{60}\right)$ to 2.03 (RCT) and from $5.53\left(\mathrm{a}_{60}\right)$ to $7.47\left(\mathrm{k}_{20}\right)$, respectively.

Only Dal Zotto et al. (2008) and De Marchi et al. (2009) assessed the ability of MIR spectroscopy to predict RCT and $\mathrm{a}_{30}$, whereas no studies investigated the potential of MIR spectroscopy to predict the MCP of samples that coagulate beyond 30 min after rennet addition. Prediction models for RCT and $\mathrm{a}_{30}$ were notably better than those reported by Dal Zotto et al. (2008) and De Marchi et al. (2009) in milk with preservatives; the authors reported 1-VR for $\mathrm{a}_{30}$ that ranged from 0.55 to 0.73 and 0.35 to 0.45 , respectively. Nevertheless, the reference method (Computerized Renneting Meter) used in these studies was different than that adopted in the present research (Formagraph). The reference method plays a key role in determining the accuracy of prediction models, as reported by Rutten et al. (2009) and De Marchi et al. (2011) for milk FA. Also, the rennet used by Dal Zotto et al. (2008) and De Marchi et al. (2009) was different than that adopted in the present work. The implementation of different methodologies to assess MCP was investigated by Pretto et al. (2011), who proposed a method for the transformation of values of MCP obtained from different methodologies, and by Cipolat-Gotet et al. (2012), who compared MCP determined with an optical instrument, the Optigraph, with MCP obtained from the Formagraph.

Results of the present study highlighted the potential of MIR spectroscopy to predict $k_{20}$. Curd-firming time is considered a trait of great practical importance in 
Table 2. Fitting statistics ${ }^{1}$ of prediction models for milk coagulation properties

\begin{tabular}{lccccccc}
\hline Trait $^{2}$ & $\# \mathrm{~L}$ & $\mathrm{SEC}$ & $\mathrm{R}^{2}$ & $\mathrm{SEC}_{\mathrm{CV}}$ & 1-VR & RPD & RER \\
\hline $\mathrm{RCT}, \min$ & 15 & 6.14 & 0.82 & 7.05 & 0.76 & 2.03 & 7.28 \\
$\mathrm{k}_{20}$, min & 12 & 2.94 & 0.80 & 3.54 & 0.72 & 1.86 & 7.47 \\
$\mathrm{a}_{30}, \mathrm{~mm}$ & 17 & 5.06 & 0.87 & 7.68 & 0.70 & 1.80 & 6.63 \\
$\mathrm{a}_{60}, \mathrm{~mm}$ & 12 & 6.20 & 0.56 & 7.26 & 0.40 & 1.26 & 5.53 \\
\hline
\end{tabular}

${ }^{1} \# \mathrm{~L}=$ number of modified partial least squares factors used in the calibration; SEC $=$ standard error of calibration; $\mathrm{SEC}_{\mathrm{CV}}=$ standard error of cross-validation; $1-\mathrm{VR}=$ coefficient of determination of cross-validation; $\mathrm{RPD}=$ ratio performance deviation; $\mathrm{RER}=$ range error ratio.

${ }^{2} \mathrm{RCT}=$ rennet coagulation time of samples that coagulated within $60 \mathrm{~min}$ from enzyme addition; $\mathrm{k}_{20}=$ curdfirming time of samples attaining $20 \mathrm{~mm}$ of firmness within $60 \mathrm{~min}$ from enzyme addition; $\mathrm{a}_{30}=$ curd firmness 30 min after enzyme addition; $a_{60}=$ curd firmness 60 min after enzyme addition.

the dairy industry, as it suggests the optimal time at which curd-cutting should commence, and thus it is related to product yield and quality (Bynum and Olson, 1982). However, $\mathrm{k}_{20}$ has not been widely studied in the past, as it is available only for samples attaining $20 \mathrm{~mm}$ of curd firmness and, thus, not for NC milks. To our knowledge, this is the first study attempting to predict $\mathrm{k}_{20}$ for samples that coagulated beyond $30 \mathrm{~min}$ from enzyme addition using MIR spectroscopy. The worst prediction model developed in the present research was for $\mathrm{a}_{60}$. The low accuracy of prediction might be related to the low accuracy of reference analysis for

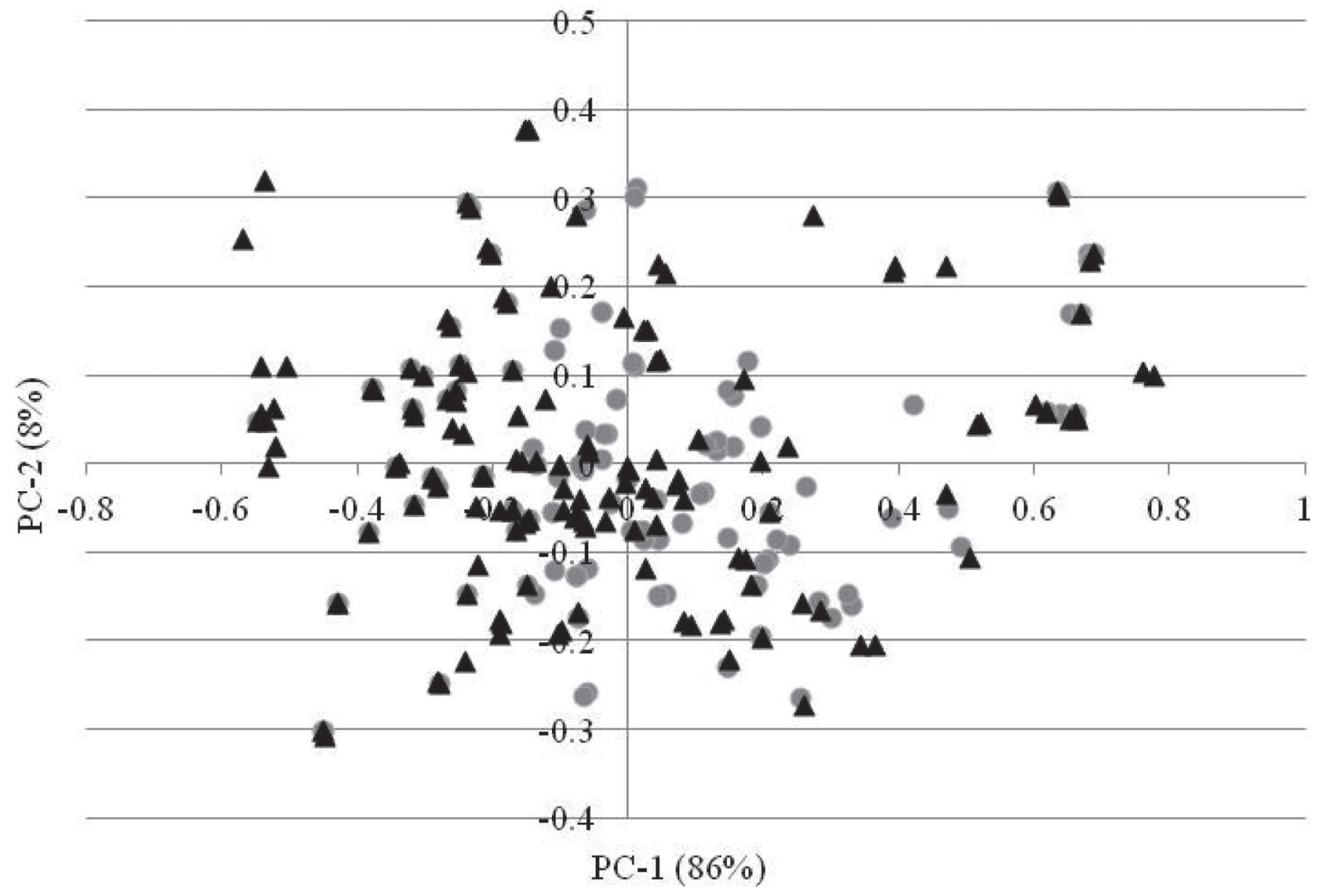

Figure 1. Plot of first (PC-1) and second (PC-2) components from principal component analysis of spectral data. Triangles $=$ samples with rennet coagulation time equal to or longer than 30 min; Circles = samples with rennet coagulation time shorter than 30 min. 

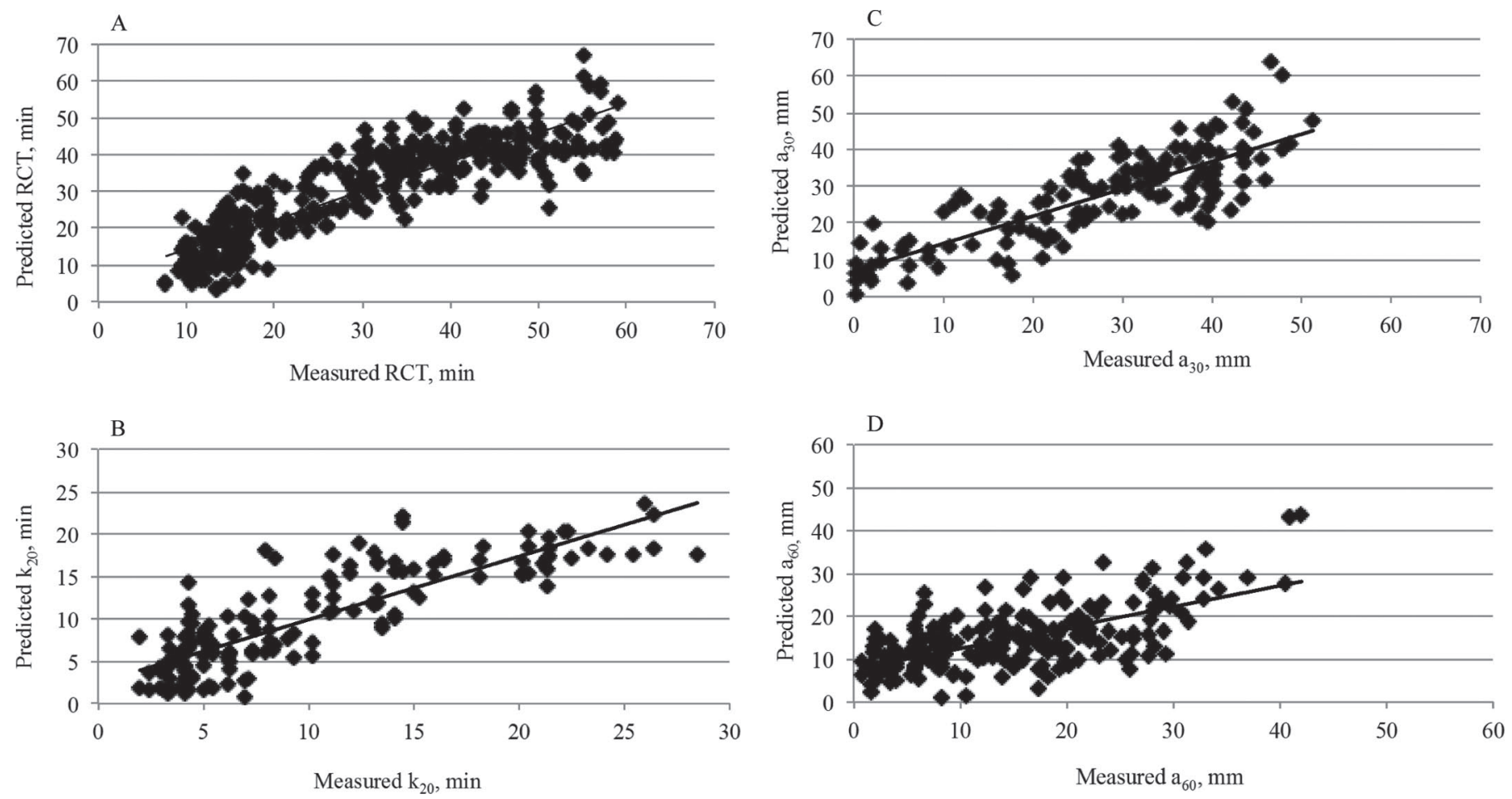

Figure 2. Scatter plots of predicted (y-axis) versus measured (x-axis) milk coagulation properties. (A) Rennet coagulation time of samples that coagulated within 60 min from enzyme addition (RCT); (B) curd-firming time of samples attaining $20 \mathrm{~mm}$ of firmness within 60 min from enzyme addition $\left(\mathrm{k}_{20}\right)$; $(\mathrm{C})$ curd firmness 30 min after enzyme addition $\left(\mathrm{a}_{30}\right)$; and $(\mathrm{D})$ curd firmness 60 min after enzyme addition $\left(\mathrm{a}_{60}\right)$.

NC samples. This was reported by Cipolat-Gotet et al. (2012), who found large variability for curd firmness measured $45 \mathrm{~min}$ after rennet addition.

The scatter plots of predicted versus measured MCP are shown in Figure 2. A quite high degree of scatter was observed for $\mathrm{a}_{60}$, indicating that the current model is not enough accurate to be used in the dairy industry, but demonstrates the potential of MIR spectroscopy to predict $\mathrm{a}_{60}$.

To investigate the molecular basis of MCP, the \#L weight of the first, second, and third PLS components of prediction models were examined (Figure 3). Considerable structure in the \#L plots of all studied traits was noted. In general, the pattern of \#L weight of RCT and $k_{20}$ was specular to that of $a_{30}$ and $a_{60}$. Several peaks were observed in the fingerprint region from 900 to $1,500 \mathrm{~cm}^{-1}$ (e.g., 992, 1,138, and $1,184 \mathrm{~cm}^{-1}$ ) of the spectra, and this might be attributable to $\mathrm{C}-\mathrm{O}$ or $\mathrm{C}-\mathrm{C}$ stretching. Characteristic peaks were also observed from 1,543 to $1,593 \mathrm{~cm}^{-1}$, which can be attributed to amide II. Peaks associated with lipids (from 2,828-2,970, and from $1,751-1,763 \mathrm{~cm}^{-1}$ ) were also apparent in \#L 1, 2, and 3 , as well as peaks from 1,238 and $1,265 \mathrm{~cm}^{-1}$ and from 1,455 to $1,462 \mathrm{~cm}^{-1}$, which may be attributable to $\mathrm{O}-\mathrm{C}-\mathrm{H}, \mathrm{C}-\mathrm{C}-\mathrm{H}$, or $\mathrm{C}-\mathrm{O}-\mathrm{H}$ bending. The peaks associated with protein were found to be very dominant for
$\mathrm{RCT}$ and $\mathrm{k}_{20}$, whereas those associated with lipids seem to be more dominant for curd firmness traits. These results highlighted the role of protein and lipid regions of the MIR spectra to predict MCP, and coincided with findings of De Marchi et al. (2009) and of several authors who reported the effect of protein and fat content on milk coagulation (Bastian et al., 1991; Castillo et al., 2003).

\section{CONCLUSIONS}

Mid-infrared spectroscopy combined with PLS regressions has been proposed as potential tool to predict $\mathrm{RCT}, \mathrm{k}_{20}, \mathrm{a}_{30}$, and $\mathrm{a}_{60}$ in bovine milk samples. Results indicated that the prediction performance of the MIR technique was satisfactory for RCT measured up to 60 min from rennet addition, as well as for $\mathrm{k}_{20}$ and $\mathrm{a}_{30}$, and thus it might be used in payment systems to reward or penalize milk according to MCP. The prediction of MCP in milk samples that coagulate beyond $30 \mathrm{~min}$ from rennet addition ( $\mathrm{NC}$ samples) may have a great importance in genetic evaluation of animals for MCP. In fact, until now MCP information from NC samples has been often discarded from genetic analysis, leading to possible biases in the prediction of sires merit for coagulation traits. 
A

- L1 --- L2 - - - L3

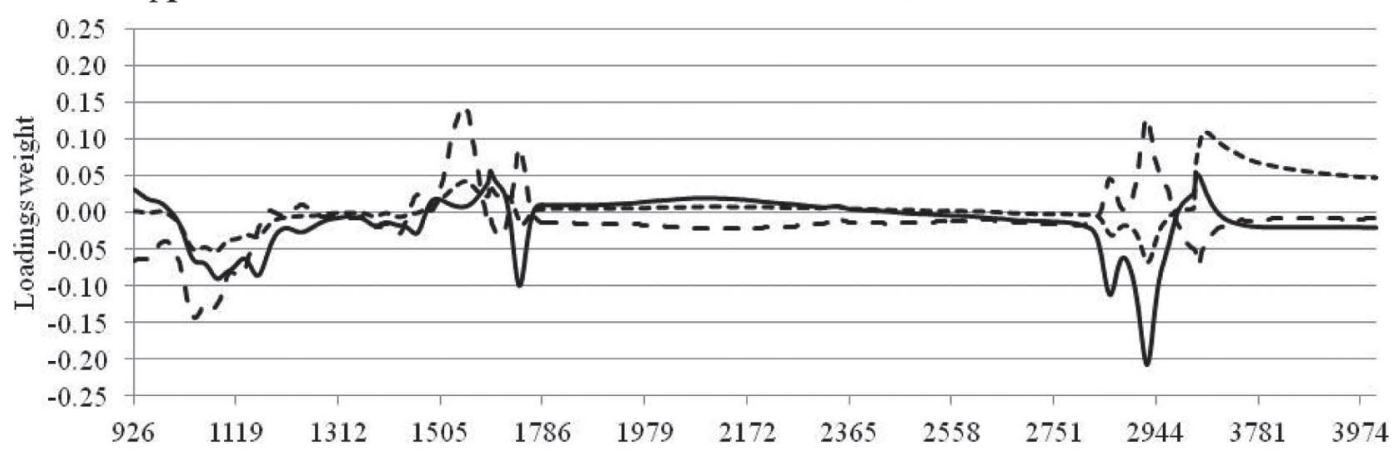

B

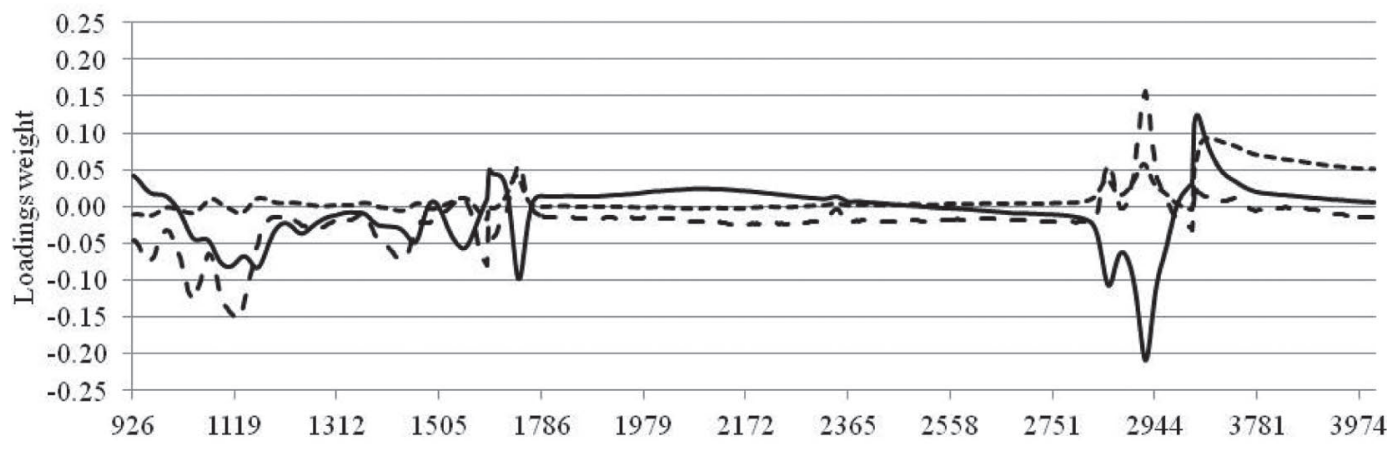

$\mathrm{C}$

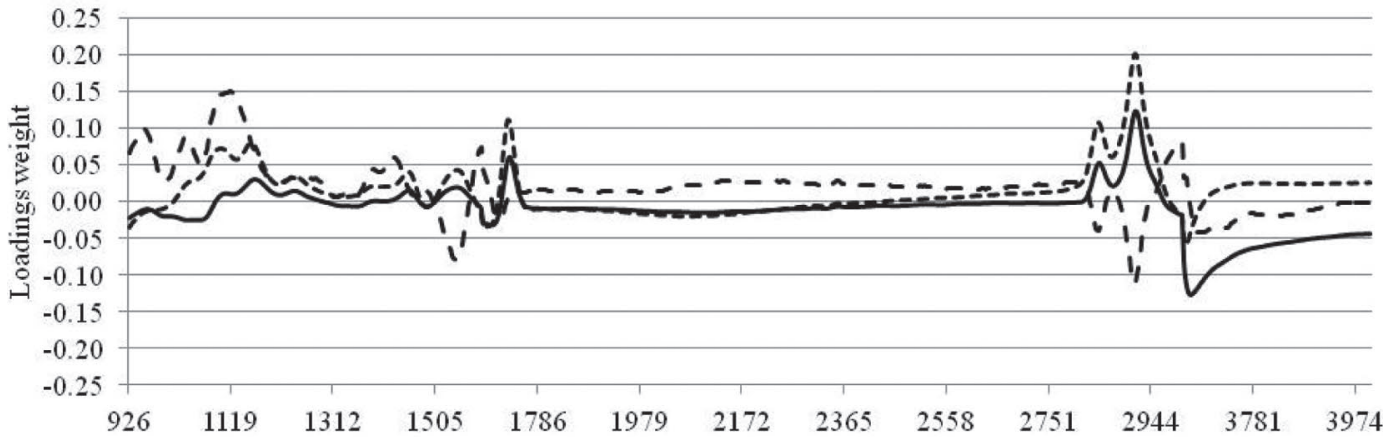

$\mathrm{D}$

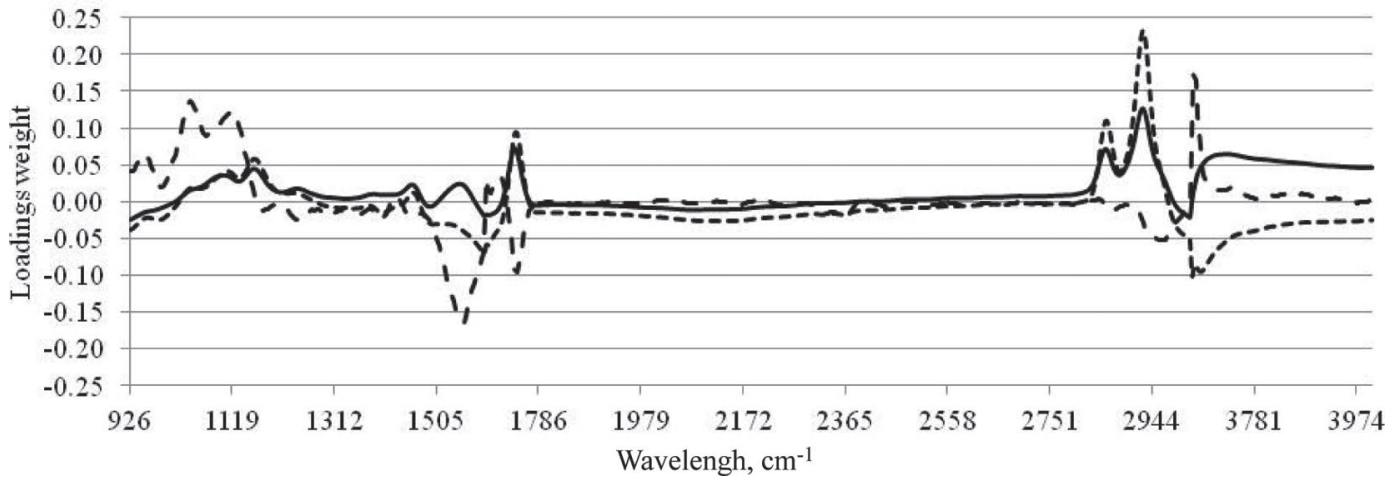

Figure 3. Loadings weight of the first (\#L1), second (\#L2), and third (\#L3) partial least squares regression component for (A) rennet coagulation time of samples that coagulated within 60 min from enzyme addition; (B) curd-firming time of samples attaining 20 mm of firmness within 60 min from enzyme addition; (C) curd firmness 30 min after enzyme addition; and (D) curd firmness 60 min after enzyme addition. 


\section{ACKNOWLEDGMENTS}

The authors thank the milk laboratory of the Breeders Association of Veneto region (ARAV, Padova, Italy) and Lucia Ancilotto (University of Padova, Italy) for technical support. The authors thank the CheeseBull project PSR124 for financial support.

\section{REFERENCES}

Auldist, M., C. Mullins, B. O'Brien, B. T. O'Kennedy, and T. Guinee. 2002. Effect of cow breed on milk coagulation properties. Milchwissenschaft 57:140-143.

Auldist, M. J., K. A. Johnston, N. J. White, W. P. Fitzsimons, and M. J. Boland. 2004. A comparison of the composition, coagulation characteristics and cheesemaking capacity of milk from Friesian and Jersey dairy cows. J. Dairy Res. 71:51-57.

Bastian, E. D., R. J. Brown, and C. A. Ernstrom. 1991. Plasmin activity and milk coagulation. J. Dairy Sci. 74:3677-3685

Bynum, D. G., and N. F. Olson. 1982. Influence of curd firmness at cutting on Cheddar cheese yield and recovery of milk constituents. J. Dairy Sci. 65:2281-2290.

Cassandro, M., A. Comin, M. Ojala, R. Dal Zotto, M. De Marchi, L. Gallo, P. Carnier, and G. Bittante. 2008. Genetic parameters of milk coagulation properties and their relationships with milk yield and quality traits in Italian Holstein cows. J. Dairy Sci. 91:371-376.

Castillo, M., F. A. Payne, C. L. Hicks, J. Laencina, and M. B. Lopez. 2003. Effect of protein and temperature on cutting time prediction in goats' milk using an optical reflectance sensor. J. Dairy Res. 70:205-215.

Cecchinato, A., M. De Marchi, L. Gallo, G. Bittante, and P. Carnier 2009. Mid-infrared spectroscopy predictions as indicator traits in breeding programs for enhanced coagulation properties of milk. J. Dairy Sci. 92:5304-5313.

Cecchinato, A., M. Penasa, M. De Marchi, L. Gallo, G. Bittante, and P. Carnier. 2011. Genetic parameters of coagulation properties, milk yield, quality, and acidity estimated using coagulating and noncoagulating milk information in Brown Swiss and HolsteinFriesian cows. J. Dairy Sci. 94:4205-4213.

Cipolat-Gotet, C., A. Cecchinato, M. De Marchi, M. Penasa, and G. Bittante. 2012. Comparison between mechanical and near-infrared methods for assessing coagulation properties of bovine milk. J. Dairy Sci. 95:6806-6819.

Coates, J. 2000. Interpretation of infrared spectra, a practical approach. Pages 10,815-10,837 in Encyclopedia of Analytical Chemistry. R. A. Meyers, ed. John Wiley \& Sons, New York, NY.

Curley, D. M., T. F. Kumosinski, J. J. Unruh, and H. M. Farrell Jr.. 1998. Changes in the secondary structure of bovine casein by Fourier transform infrared spectroscopy: Effects of calcium and temperature. J. Dairy Sci. 81:3154-3162.

Dal Zotto, R., M. De Marchi, A. Cecchinato, M. Penasa, M. Cassandro, P. Carnier, L. Gallo, and G. Bittante. 2008. Reproducibility and repeatability of measures of milk coagulation properties and predictive ability of mid-infrared reflectance spectroscopy. J. Dairy Sci. 91:4103-4112.

De Marchi, M., G. Bittante, R. Dal Zotto, C. Dalvit, and M. Cassandro. 2008. Effect of Holstein-Friesian and Brown Swiss breeds on quality of milk and cheese. J. Dairy Sci. 91:4092-4102.

De Marchi, M., C. C. Fagan, C. P. O'Donnell, A. Cecchinato, R. Dal Zotto, M. Cassandro, M. Penasa, and G. Bittante. 2009. Prediction of coagulation properties, titratable acidity, and $\mathrm{pH}$ of bovine milk using mid-infrared spectroscopy. J. Dairy Sci. 92:423-432.

De Marchi, M., M. Penasa, A. Cecchinato, M. Mele, P. Secchiari, and G. Bittante. 2011. Effectiveness of mid-infrared spectroscopy to predict fatty acid composition of Brown Swiss bovine milk. Animal 5:1653-1658.
De Marchi, M., M. Penasa, F. Tiezzi, V. Toffanin, and M. Cassandro. 2012. Prediction of milk coagulation properties by Fourier transform mid-infrared spectroscopy (FTMIR) for genetic purposes, herd management and dairy profitability. In 38th International Committee for Animal Recording (ICAR) Meeting, May 28 to June 1, Cork, Ireland. http://www.icar.org/Cork_2012/Manuscripts/Published/Cassandro.pdf.

Edney, M. J., J. E. Morgan, P. C. Williams, and L. D. Campbell. 1994. Analysis of feed barley by near infrared reflectance technology. J. Near Infrared Spectrosc. 2(Spec.):33-41.

Etzion, Y., R. Linker, U. Cogan, and I. Shmulevich. 2004. Determination of protein concentration in raw milk by mid-infrared Fourier transform infrared/attenuated total reflectance spectroscopy. J. Dairy Sci. 87:2779-2788.

Frederiksen, P. D., K. K. Andersen, M. Hammersh øj, H. D. Poulsen, J. Sørensen, M. Bakman, K. B. Qvist, and L. B. Larsen. 2011. Composition and effect of blending of noncoagulating, poorly coagulating, and well-coagulating bovine milk from individual Danish Holstein cows. J. Dairy Sci. 94:4787-4799.

Hallén, E. A. Lundén, A.-M. Tyrisevä, M. Westerlind, and A. Andrén. 2010. Composition of poorly and non-coagulating bovine milk and effect of calcium addition. J. Dairy Res. 77:398-403.

Harzia, H., K. Kilk, I. Jõudu, M. Henno, O. Kärt, and U. Soomets. 2012. Comparison of the metabolic profiles of noncoagulating and coagulating bovine milk. J. Dairy Sci. 95:533-540.

Hewavitharana, A. K., and B. V. Brakel. 1997. Fourier transform infrared spectrometric method for rapid determination of casein in raw milk. Analyst (Lond.) 122:701-704.

Ikonen, T., K. Ahlfors, R. Kempe, M. Ojala, and O. Ruottinen. 1999 Genetic parameters for the milk coagulation properties and prevalence of noncoagulating milk in Finnish dairy cows. J. Dairy Sci. $82: 205-214$

Ikonen, T., S. Morri, A.-M. Tyrisevä, O. Ruottinen, and M. Ojala. 2004. Genetic and phenotypic correlations between milk coagulation properties, milk production traits, somatic cell count, casein content, and pH of milk. J. Dairy Sci. 87:458-467.

Jørgensen, K., and T. Næs. 2004. A design and analysis strategy for situations with uncontrolled raw material variation. J. Chemometr. 18:45-52.

Lefèvre, T., and M. Subirade. 2000. Interaction of $\beta$-lactoglobulin with phospholipids bilayers: A molecular level elucidation as revealed by infrared spectroscopy. Int. J. Biol. Macromol. 28:59-67.

Mariani, P., A. Summer, G. Zanzucchi, and S. Fieni. 1997. Relazione tra la consistenza del coagulo-Valutata con differenti criteri mediante Formagraph - e il contenuto in caseina del latte. Annali della Facoltà di Medicina Veterinaria di Parma 17:195-204.

Martens, H., and T. Naes. 1989. Models for calibration. Chapter 3 in Multivariate Calibration. H. Martens and T. Naes, ed. John Wiley \& Sons Ltd., London, UK.

O'Brien, B., G. Ryan, W. J. Meaney, D. McDonagh, and A. Kelly. 2002. Effect of frequency of milking on yield, composition and processing quality of milk. J. Dairy Res. 69:367-374.

Okigbo, L. M., G. H. Richardson, R. J. Brown, and C. A. Ernstrom. 1985a. Coagulation properties of abnormal and normal milk from individual cow quarters. J. Dairy Sci. 68:1893-1896.

Okigbo, L. M., G. H. Richardson, R. J. Brown, and C. A. Ernstrom. 1985b. Effects of $\mathrm{pH}$, calcium chloride, and chymosin concentration on coagulation properties of abnormal and normal milk. J. Dairy Sci. 68:2527-2533.

Okigbo, L. M., G. H. Richardson, R. J. Brown, and C. A. Ernstrom. 1985c. Variation in coagulation properties of milk from individual cows. J. Dairy Sci. 68:822-828.

Penasa, M., M. Cassandro, D. Pretto, M. De Marchi, A. Comin, S. Chessa, R. Dal Zotto, and G. Bittante. 2010. Short communication: Influence of composite casein genotypes on additive genetic variation of milk production traits and coagulation properties in Holstein-Friesian cows. J. Dairy Sci. 93:3346-3349.

Pillonel, L., W. Luginbühl, D. Picque, E. Schaller, R. Tabacchi, and J. O. Bosset. 2003. Analytical methods for the determination of the geographic origin of Emmental cheese: Mid- and near-infrared spectroscopy. Eur. Food Res. Technol. 216:174-178. 
Pretto, D., M. De Marchi, M. Penasa, and M. Cassandro. 2013. Effect of milk composition and coagulation traits on Grana Padano cheese yield under field conditions. J. Dairy Res. 80:1-5.

Pretto, D., T. Kaart, M. Vallas, I. Jõudu, M. Henno, L. Ancilotto, M. Cassandro, and E. Pärna. 2011. Relationships between milk coagulation property traits analyzed with different methodologies. J. Dairy Sci. 94:4336-4346.

Riddell-Lawrence, S., and C. L. Hicks. 1989. Effect of curd firmness on stirred curd cheese yield. J. Dairy Sci. 72:313-321.

Rutten, M. J. M., H. Bovenhuis, K. A. Hettinga, H. J. F. van Valenberg, and J. A. M. van Arendonk. 2009. Predicting bovine milk fat composition using infrared spectroscopy based on milk samples collected in winter and summer. J. Dairy Sci. 92:6202-6209.

Sandri, S., F. Tosi, M. S. Mariani, P. Vecchia, M. Malacarne, and A. Summer. 2001. Osservazioni sull'andamento delle principali caratteristiche casearie del latte per Parmigiano-Reggiano durante gli anni 1990. Ann. Fac. Med. Vet. University of Parma 21:235-247.

Sinnaeve, G., P. Dardenne, R. Agneessens, and R. Biston. 1994. The use of near infrared spectroscopy for the analysis of fresh grass silage. J. Near Infrared Spectrosc. 2(Spec.):79-84.

Tyrisevä, A.-M., K. Elo, A. Kuusipuro, V. Vilva, I. Jänönen, H. Karjalainen. T. Ikonen, and M. Ojala. 2008. Chromosomal regions underlying noncoagulation of milk in Finnish Ayrshire cows. Genetics 180:1211-1220.

Tyrisevä, A.-M., T. Ikonen, and M. Ojala. 2003. Repeatability estimates for milk coagulation traits and non-coagulation of milk in Finnish Ayrshire cows. J. Dairy Res. 70:91-98.
Tyrisevä, A.-M., T. Vahlsten, O. Ruottinen, and M. Ojala. 2004 Noncoagulation of milk in Finnish Ayrshire and Holstein-Friesian cows and effect of herds on milk coagulation ability. J. Dairy Sci. 87:3958-3966.

Vallas, M., H. Bovenhuis, T. Kaart, K. Pärna, H. Kiiman, and E. Pärna. 2010. Genetic parameters for milk coagulation properties in Estonian Holstein cows. J. Dairy Sci. 93:3789-3796.

Wedholm, A., L. B. Larsen, H. Lindmark-Månsson, A. H. Karlsson, and A. Andrén. 2006. Effect of protein composition on the cheesemaking properties of milk from individual dairy cows. J. Dairy Sci. 89:3296-3305.

Williams, P. C. 2001. Implementation of near-infrared technology. Page 143 in Near-Infrared Technology in the Agricultural and Food Industries, 2nd ed. P. C. Williams \& K. Norris, ed. American Association of Cereal Chemists, St. Paul, MN.

Williams, P. C. 2003. Near-infrared technology getting the best out of light. Page 109 in A Short Course in the Practical Implementation of Near Infrared Spectroscopy for the User. 1.1 ed. PDKProjects Inc., Nanaimo, Canada.

Williams, P. C., and K. Norris. 2001. Near-Infrared Technology in the Agricultural and Food Industries. 2nd ed. American Association of Cereal Chemists Inc., St. Paul, MN. 